\title{
The Influence of Emotional Motives on the Decision to Use a Credit Card
}

\author{
Kasnaeny Karim ${ }^{\mathrm{a}, *}$, Muhammad Jibril Tajibu ${ }^{\mathrm{b}}$ \\ ${ }^{a}$ Departement of Management, Faculty of Economics and Business, Universitas Muslim Indonesia Makassar, Indonesia \\ ${ }^{b}$ Departement of Economics, Faculty of Economics and Business, Universitas Hasanuddin Makassar, Indonesia
}

\begin{abstract}
The purpose of this study was to analyze the influence of emotional motives consisting of personal factors and psychological factors on consumer decisions to use credit cards. This study involved 100 respondents, with a sampling technique based on purposive sampling. The questionnaire was distributed to respondents according to the research criteria, namely being customers of credit card users in banks in the city of Makassar, which were further analyzed using the Multiple Linear Regression model, which will test variables from emotional motives, namely personal factors, and psychological factors, on the decision to use credit cards. . The results showed that personal factors had a significant positive effect on the decision to use a credit card, while psychological factors also showed a significant positive effect on the decision to use a credit card. Thus, people in the city of Makassar use credit cards based on the encouragement of emotional motives consisting of personal factors and psychological factors.
\end{abstract}

Keywords: emotional motive, personal factor, psychological factor, decision, credit card

\section{INTRODUCTION}

The growth of credit card use in Indonesia is currently increasing. This can be seen from the number of types of credit cards issued, the increase in the number of customers, and the number and value of credit cards in circulation which jumped very rapidly between 2005 and 2010 (Rahayu, F., Irmawati Hermuningsih, 2011). However, there is a different phenomenon that there was a decrease in the number of credit cards in circulation, namely at the beginning of 2017, the number of credit cards in circulation was recorded at 17.49 million pieces, but in August the number of credit cards experienced the decline was only 16.89 million pieces. The reason is the existence of provisions from Bank Indonesia (BI) that limit the number of credit card ownership for certain incomes (Laucereno, 2017).

A credit card is a payment instrument that is commonly used in the payment of a transaction or as a substitute for cash. At times, credit cards can be used to buy or pay for whatever we want at any place that accepts the credit card or it can also be cashed. Credit cards have now become a lifestyle and part of the human community to be categorized as modern in the life order of a city that is moving metropolitan. Regarding lifestyle, according to Fauzan (2017) who cites the opinion of Rhenald

\footnotetext{
*Author in correspondence,

Email address: kasnaeny@umi . ac. id (Kasnaeny Karim)
}

ISSN: 2549-3221 (Print) 2549-323X (Online)

DOI: $10.26487 /$ hebr.v5i2.2951
Kasali (2007) that a study conducted by Euromonitor International shows that in a period of 25 years (1990-2015) Indonesian households experienced an extraordinary consumption revolution. This data is reinforced by an increase in the use of consumer credit, which rose drastically, Rp. 297,586 trillion (the year 2000) to Rp. 566,896 trillion (the year 2004). This indicates that the use of credit cards is often associated with use for consumption.

Thus it can be said, that the use of credit cards is certainly driven by certain motives that lead to the desire to consume. Meanwhile, according to Kotler and Keller (2012) that the consumer's decision to use/make a purchase is influenced by psychological factors, which psychological factors consist of motivation and perception. Motivation is a strong impulse that directs a person's behavior in the desired direction. The impulse can come from rational motives and emotional motives. This can be seen from the results of research (Fauzan, 2017), which shows that a person's lifestyle affects the use of credit cards. But on the other hand, Henegar et al. (2013) stated that credit cards are part of the creation of impulsive buying.

Thus, there is an emotional motive that underlies a person in purchasing. Emotional motives are closely related to internal consumer decisions, which means that consumers buy. They are motivated by decisions that come from internal considerations, for example, the product matches their personality or attitude, or because they want to own a product because the product is very rare. Emotional motives are purchase motives related to individual feelings or emotions. For example, they shop not be- 
cause of the function of a product but because they like it, are proud to use it, it's a trend, there is prestige when using, or want to imitate the product used by their idol, or whoever is the reference. The emotional motive of the purchase motive is based on feelings, and it appears that consumers act in a hurry when buying a product so that they do not consider the possibilities that might occur in the long term (Hakim, 2018). Emotional action is also a person's personal encouragement to carry out an activity, where emotional motives include (1) personal factors, and (2) psychological factors.

Studies on emotional motives have been carried out, for example by Hoque et al. (2012) which states that emotional actions have a strong role in purchasing decision behavior in Bangladesh. Meanwhile, studies on the relationship between credit card use and emotional decisions that specifically examine consumers in Makassar have not been found. The visible phenomenon is that consumers in Makassar, for one person, can have several types of credit cards. Based on the above study, the problem to be solved is whether emotional motives, consisting of personal factors and psychological factors, influence consumer decisions to use credit cards. The results of this study are expected to be an input for the banking industry in credit card distribution so that there is no risk due to excessive use. It is also expected to provide information for consumers regarding the importance of using credit cards wisely in shopping.

\section{LITERATURE REVIEW}

\subsection{Consumer emotional motives}

Emotional motives are part of the hedonic motive, where the hedonic motive is a shopping urge that arises based on consumption experiences related to feelings, fantasies, pleasures, and the five senses, where these experiences affect one's emotions (Ryu et al., 2010). According to Engel et al. (1995) the criteria used when considering hedonic values are subjective and symbolic, centering on the notion of a product or service that is independent of objective considerations.

Hedonic shopping behavior, which is shopping behavior related to recreational, pleasure, intrinsic, and stimulation aspects, causes consumers who shop to have subjective values that have the potential to provide entertainment in shopping so that consumers feel they will receive benefits without having to buy them (for example, fun activities, entertainment, fantasy, sensory stimulation) as well as refer to the value received from fantasy, and multi-sensory aspects of shopping. Customers who have high values on hedonic motives are more interested in the act of shopping alone or independently and it is important to see self-expression and personal satisfaction associated with shopping (Yavas and Babakus, 2009). Likewise, customers who shop driven by hedonic value will shop based on emotion or feelings that come from the environment and experiences.

Emotional action is also a person's personal encouragement to carry out an activity with emotional encouragement so that people can act according to their wishes. Emotional factors are pride, self-confidence, and satisfaction. Purchasing products based on emotional reasons sometimes includes only a few logical things and more come from the heart, not from a mature mind (Hoque et al., 2012).

Schiffman and Kanuk (2009) states that the term emotional is used when the purchase choice is determined based on subjective selective criteria. Some of the factors included in emotional motivation are safety, comfort, ego, pride, recreation, sex, competition, health, practicality, and so on. Purchases based on emotional motivation occur during the process of selecting goods or services, based on subjective and personal reasons, such as pride, fear, affection, or status.

The assumption that underlines the difference between emotional purchase motivation and rational purchase motivation is that emotional purchase motivation is often considered not to take maximum utility or satisfaction into account, however, it is reasonable to say that consumers always try to select alternatives that they think can provide satisfactory satisfaction. maximum. It is quite clear that the measure of satisfaction is very personal in nature, based on the structure of the needs of each individual, past experiences, and behavior (learned) from the environment. What seems irrational to others, can be considered rational in the consumer's thinking. For example, someone who does plastic surgery to look younger is seen to use significant economic resources such as surgery costs, time to recover, inconvenience, and considerable risk if something goes wrong in surgery. For that person, the goal is to look younger, and all the costs and risks involved are perfectly rational. But for many other people in the same culture, who don't pay attention to age, or appearance 20 , the actions taken by that person are irrational (Schiffman and Kanuk, 2009).

\subsection{Personal Factors}

Personal factors are the characteristics of a person, where these characteristics differ from one person to another. Kotler and Keller (2012) states that individual decision-making to consume something is determined by personal characteristics, where the dimensions consist of (1) Age and Life Cycle Stage, (2) Occupation, (3) Economy, (4) Lifestyle, and (5) Self-concept. The influence of individual characteristics is also stated by Sarker (2013) that can influence purchasing decisions, with the same indicators as the statements of Kotler and Keller (2012). Likewise, Abdullah et al. (2017) and Susanto et al. (2016) also stated that there is an influence of personal factors on product purchasing decisions.

\subsection{Psychological Factors}

Psychological factors are factors that indicate feelings, how to collect and analyze information, and how to formulate ideas for taking action. Loken (2006) states that psychological factors consist of motivation, perception, learning, and beliefs and attitudes. The influence of psychological factors on the decision to consume products has been carried out by Fitrianingrum and Wahyono (2013), Nawawi (2016), Khosla (2018), all of which state that there is a relationship between psychological factors and purchasing decisions even though with different objects. 


\section{RESEARCH METHODS}

This study was analyzed using a quantitative approach. The quantitative method is a method based on the positivism philosophy used in the research sample and uses research instruments to collect data (Sugiyono, 2013). The research variables consist of personal factor variables $\left(X_{1}\right)$, and psychological variables $\left(X_{2}\right)$ as independent variables, and the decision to use credit cards $(\mathrm{Y})$ as the dependent variable. The analysis model used is multiple regression analysis.

The population of this research is all credit card users who become customers of banks in the city of Makassar totaling 385,000 . Given the large population and distribution of credit card users, the determination of the number of samples based on the Hier method is 5-10 times the number of research indicators, to obtain a total of 100 respondents with a sample appointment based on purposive sampling technique.

The research data was collected through a questionnaire, which contains an indicator question with 5 alternative answers based on a Likert scale. The use of the Likert scale aims to measure attitudes, opinions, and perceptions of individuals and groups of social phenomena (Feri et al., 2020).

\section{RESULT AND DISCUSSION}

This study examines the influence of emotional motives consisting of personal and psychological variables on the decision to use credit cards. Research respondents are people in the city of Makassar who use a credit card, to get their experience when they first decide to use a credit card. The results obtained were based on the characteristics of the respondents who filled out the questionnaire were men $(60 \%)$ and women $(40 \%)$, while those who filled out the most questionnaires were from the ages of $20-30$ years as many as 46 , and above $30-40$ by $28 \%$. Respondents with civil servant characteristics as much as $43 \%$, and entrepreneurship as much as $28 \%$. Characteristics based on income, the largest is an income of Rp. 1,000,000, - to Rp. $3,000,000$, - as much as $60 \%$.

The analysis used in this study is multiple regression analysis. The choice in this analysis is due to the desire to know the variables that influence consumer decisions to use credit cards. Before carrying out a regression analysis, the instrument's feasibility test was conducted first, and it can be seen in Table 1 that all indicators are valid.

Table 1: Research Instrument Test Results

\begin{tabular}{llc}
\hline Var & Variable Name & Significant Value \\
\hline$X_{1}$ & Personal Factors & 0,000 \\
$X_{2}$ & Psychological Factors & 0,000 \\
$\mathrm{Y}$ & Decision to use Credit Card & 0,000 \\
\hline & Cronbach's Alpha & $0,830>0.60$ \\
\hline
\end{tabular}

Source: the results of data processing

The results obtained after testing using simple Linear Regression Analysis, are as Table 2.
Table 2: Regression Analysis Results

\begin{tabular}{lcccl}
\hline & B & Std. Error & t & Sig \\
\hline Constant & 2.046 & 0.423 & 4.832 & 0.000 \\
$X_{1}$ & 0.439 & 0.096 & 4.597 & 0.000 \\
$X_{2}$ & 0.086 & 0.073 & 1.117 & 0.043 \\
$\mathrm{R}$ & 0.55 & & & \\
R Square & 0.26 & & & \\
\hline
\end{tabular}

Source: the results of data processing

Based on the calculation results, the equation is obtained:

$Y=2.046+0.439 X_{1}+0.086 X_{2}$

The results of the analysis can be interpreted, that personal factors and psychological factors as part of emotional motives have a significant positive effect on consumer decisions to use credit cards. The tight relationship between the $\mathrm{X}$ and $\mathrm{Y}$ variables is indicated by the correlation value of 0.550 , which means that the relationship between the variables is only 55

Thus the result shows that emotional motives with personal and psychological variables have an influence on consumer decisions to use credit cards. Personal factors with indicators of age and life cycle stages, work, economy, lifestyle, and selfconcept, the results of the analysis show that the older a person is, the more he thinks about consuming products that are appropriate to his age and life cycle. Likewise, the more stable a person's job is, the more he looks for products that make it easier for him to purchase products. In terms of economic conditions, the more stable a person's economy is, they have thought of using products that are following their economic level, where a credit card also symbolizes a lifestyle and supports one's selfconcept to get recognition from others.

Psychological factors too, the better a person's psychological condition, the stronger the person's decision to use a credit card. The results of the analysis show that this factor has a significant positive effect on the decision to use credit cards. Indicators of psychological factors are motivation, perception, learning, and beliefs and attitudes. The meaning that can be elaborated is that the stronger a person's motivation for a certain product, the more his decision to use the product will be increased.

Likewise regarding a person's perception, where the better the product is perceived by consumers, the more it will strengthen the decision to use the desired product. Consumers before using the product will seek information first. This information will be studied by considering the advantages and disadvantages of the product based on other people's experiences, the better learning about credit cards that will be obtained, the more it will strengthen the decision to use a credit card. Beliefs and attitudes towards credit card products also influence the decision to use credit cards. Consumers who believe in the benefits and have a positive attitude towards credit cards will further strengthen the decision to use the credit card. 


\section{CONCLUSION}

Based on the results of the analysis, the study concluded that emotional motives consisting of personal and psychological factors partially have a significant positive effect on the decision to use credit cards by consumers in the city of Makassar.

The advice given to banks is to pay attention to consumers' emotional motives because consumers sometimes act not with rational thought, but also based on emotional impulses.

Further researchers need to conduct in-depth research on emotional motives because there are many other variables that shape consumer emotional motives, which in this study only tested two variables, namely personal and psychological. This is shown from the $\mathrm{R}$ square value, which is only $26 \%$, which means that $74 \%$ of other variables can influence consumer decisions based on emotional motives.

\section{References}

Abdullah, R. R., Yulianto, E., Mawardi, M. K., 2017. Pengaruh Sikap, Faktor Pribadi, Dan Faktor Sosial Terhadap Keputusan Pembelian (Survey pada Konsumen Kartu Perdana SimPATI di GraPARI Malang). Jurnal Administrasi Bisnis S 42 (1), 110-114.

Engel, J. F., Blackwell, R. D., Miniard, P. W., 1995. Consumer Behavior, 8th Edición. Fort Worth : Dryden Press.

URL: https://www . worldcat.org/title/consumer-behavior/ oclc/32666931

Fauzan, M., apr 2017. Gaya Hidup Nasabah dan Keputusan Penggunaan Kartu Kredit. Jurnal Bisnis Dan Manajemen 7, 181-192.

URL: https://doi.org/10.15408/ess.v7i2.4987

Feri, S., Rahmat, A., Supeno, B., 2020. Pengaruh Motivasi, Gaya Kepemimpinan Transformasional Dan Budaya Organisasi Terhadap Kinerja Karyawan Melalui Kepuasan Kerja Sebagai Variabel Intervening Studi Pada PT. Champion Kurnia Djaja Technologies. INOBIS: Jurnal Inovasi Bisnis Dan Manajemen Indonesia 4 (1), 134-151.

URL: https://doi.org/10.31842/jurnalinobis.v4i1.172

Fitrianingrum, F., Wahyono, T. E., 2013. Pengaruh Harga Dan Mutu Terhadap Keputusan Pembelian Kartu Seluler. Jurnal Ekonomi MODERNISASI 9 (2), 120.

URL: https://doi.org/10.21067/jem.v9i2. 202

Hakim, F. F., 2018. Pengaruh motif Rasional dan Motif Emosional Terhadap Keputusan Pembelian Sepatu Sepak Bola Specs di Keanggotaan Persis Solo. Jurnal Ilmiah Mahasiswa FEB Universitas Brawijaya 6 (2), 1-20. URL: https://doi .org/10.7868/s0869565217060263

Henegar, J. M., Archuleta, K., Grable, J., Britt, S., Anderson, N., Dale, A., 2013. Credit card behavior as a function of impulsivity and mother's socialization factors. Journal of Financial Counseling and Planning 24 (2),
37-49.

URL: http://ovidsp.ovid.com/ovidweb.cgi?T=JS $\{\&\}$ PAGE= reference $\{\&\} D=$ psyc $10\{\&\}$ NEWS $=N\{\&\} A N=2014-06577-003$

Hoque, R., Islam, S., K., N. A., 2012. Consumer Motives Toward Apartment Purchase : A Study From Consumers 'Perspective. Journal of Business Studies, XXXIII 1.

Khosla, S. S., 07 2018. Impact of Psychological Risk Factors on the Buying Decisions of the Consumers. International Journal of Management Studies $\mathrm{V}, 54$.

URL: https://www.researchgate.net/publication/326867778_ Impact_of_Psychological_Risk_Factors_on_the_Buying_ Decisions_of_the_Consumers DOI: $10.18843 / i j m s / v 5 i 3(7) / 06$

Kotler, P., Keller, K. L., 2012. Marketing Management. En: Yagan, S. (Ed.), Prentice Hall (14th ed. Vol. 22, Issue 4). Prentice Hall.

Laucereno, S. F., 2017. Sejak Awal 2017, Jumlah Kartu Kredit Terus Turun. URL: https://finance.detik.com/moneter/d-3677481/ sejak-awal-2017-jumlah-kartu-kredit-terus-turun

Loken, B., jun 2006. Consumer psychology: Categorization, inferences, affect, and persuasion. Annual Review of Psychology 57, 453-485. URL: https://doi.org/10.1146/annurev.psych.57.102904. 190136

Nawawi, M. T., 2016. Factors of Consumer Behavior That Affect Purchasing Decisions on Blackberry Smartphone. The Winners 17 (1), 59.

URL: https://doi.org/10.21512/tw.v17i1.1810

Rahayu, F., Irmawati Hermuningsih, S., 2011. Perkembangan Kartu Kredit di Indonesia. Jurnal Majemen 1 (1), 5-13.

URL: https://jurnalfe.ustjogja.ac.id/index.php/manajemen/ article/view/129

Ryu, K., Han, H., Jang, S. S., 2010. Relationships among hedonic and utilitarian values, satisfaction and behavioral intentions in the fast-casual restaurant industry. International Journal of Contemporary Hospitality Management 22 (3), 416-432.

URL: https://doi.org/10.1108/09596111011035981

Sarker, S., 2013. Influence of Personality in Buying Consumer Goods-A Comparative Study between Neo-Freudian Theories and Trait Theory Based on Khulna Region. International Journal of Business and Economics Research $2(3), 41$.

URL: https://doi.org/10.11648/j.ijber.20130203.12

Schiffman, L. G., Kanuk, L. L., 2009. Consumer Behavior -9/E. Pearson Education.

Sugiyono, 2013. Metode Penelitian. In Alfabetha, Bandung: Vol. XX. Alphabeta.

URL: https://doi.org/10.1007/s13398-014-0173-7.2

Susanto, A. B., Lapian, J., Tumbuan, A., 2016. The Influence of Cultural, Social, Personal, and Psychological on Consumer Purchase Decision Study on Tonasa Cement Product in Manado City. Jurnal Berkala Ilmiah Efisiensi 16, 1.

Yavas, U., Babakus, E., 2009. Modeling patronage behavior: a tri-partite conceptualization. Journal of Consumer Marketing 26 (7), 516-526. URL: https://doi .org/10.1108/07363760911001574 